\title{
PENGUKURAN EFISIENSI AGROINDUSTRI PANGAN LOKAL ENBAL DENGAN PENDEKATAN DATA ENVELOPMENT ANALYSIS
}

\author{
The Measure of Efficiency of Agroindustry Enbal of Local Food \\ with Approach Data Envelopment Analysis
}

\author{
Natelda R. Timisela ${ }^{1}{ }^{*}$, Ester D. Leatemia ${ }^{1}$, Febby J. Polnaya ${ }^{2}$, dan Rachel Breemer ${ }^{2}$ \\ ${ }^{1}$ Jurusan Agribisnis, Fakultas Pertanian Universitas Pattimura \\ ${ }^{2}$ Jurusan Teknologi Hasil Pertanian, Fakultas Pertanian Universitas Pattimura \\ Jln. Ir. M. Putuhena, Kampus Poka, Ambon 97233 \\ *Penulis Korespondensi: E-mail: nateldatimisela@yahoo.com
}

\begin{abstract}
The current research aimed to analyze the relative efficiency level of enbal (sago starch) agro-industries. The relative efficiency analysis on 32 DMUs of enbal agro-industries showed that 40,63\% of the industries were efficient and $59.38 \%$ were inefficient. Every efficient DMU became the reference for the inefficient DMUs based on the suggested quality. Each DMU of the enbal agro-industries has not reached a good efficiency level, which was indicated by the average relative efficiency scale of 0.886 . This was a relatively low value, and improvements on the use of production input were needed. The analysis result on the DMUs of the enbal agro-industries which were on constant return to scale position were 40,62\%. This showed that enbal agro-industries actors have applied production input efficiently, for the production increase was equal to the use of input. In other words, the use of input was more proportional. The DMUs of enbal agro-industries which were on decreasing return to scale position were 15,63\%. This showed that the use of production input had been unsuitable so that the output decreases and the production cost increased. Meanwhile, the DMUs that were on increasing return to scale position were 43,75\%. This showed that the industry actors who used certain production input would create efficient DMUs. On the other hand, the input excess would possibly decrease the output. As a result, the industry actors should be concerned about the use of production input in order to establish business efficiency.
\end{abstract}

Keywords: DMU, efficiency, enbal of agro-industry

\begin{abstract}
ABSTRAK
Penelitian bertujuan untuk menganalisis tingkat efisiensi relatif agroindustri enbal. Analisis efisiensi relatif terhadap 32 DMU agroindustri enbal menunjukan bahwa 40,63\% efisien dan 59,38\% inefisien. Setiap DMU yang efisien dijadikan referensi untuk DMU inefisien berdasarkan bobot yang disarankan. Agroindustri enbal belum mencapai tingkatan efisiensi yang baik untuk masing-masing DMU yang ditunjukkan dengan skala efisiensi relatif rata-rata 0,886 . Nilai ini relatif rendah dan perlu adanya perbaikan-perbaikan dalam penggunaan input produksi. Hasil analisis DMU agroindustri enbal yang berada pada posisi constant return to scale sebanyak 40,62\% menunjukkan bahwa pengrajin agroindustri enbal telah menggunakan input produksi secara efisien karena kenaikan produksi sebanding dengan penggunaan input atau penggunaan input lebih proporsional. DMU agroindustri enbal yang berada pada posisi decreasing return to scale sebanyak 15,63\% menunjukkan bahwa penggunaan input produksi belum tepat sehingga akan menurunkan output dan terjadi peningkatan biaya produksi. Sedangkan DMU yang berada pada posisi increasing return to scale sebanyak $43,75 \%$ menunjukkan bahwa pengrajin menggunakan input produksi tertentu akan menghasilkan DMU efisien, namun kelebihan input dapat menurunkan output sehingga pengrajin harus memperhatikan penggunaan input produksi untuk menghasilkan efisiensi usaha.
\end{abstract}

Kata kunci: agro-industri enbal, DMU, efisiensi

\section{PENDAHULUAN}

Ubi kayu merupakan tanaman serbaguna, dimanfaatkan untuk berbagai keperluan industri. Batang ubi kayu dimanfaatkan untuk bibit, papan partikel, kerajinan, briket dan arang. Daun untuk makanan, farmasi dan industri pakan ternak. Kulit umbi digunakan sebagai pakan ternak, dan daging umbi diolah menjadi produk makanan, tapioka, gaplek, tepung MOCAF, dekstrin, perekat, bioetanol, dan lain-lain. Komposisi proksimat menunjukkan bahwa kadar air pati ubi kayu bervariasi antara 11,6913,52\%, kadar abu 0,09-0,10\%, serat kasar 
0,015-0,024\% (Augustyn et al., 2007), kadar lemak $0,32 \%$, dan kadar protein $0,28 \%$ (Polnaya et al., 2015). Ubi kayu toleran terhadap tanah dengan tingkat kesuburan rendah, mampu berproduksi baik pada lingkungan sub-optimal, dan mempunyai pertumbuhan yang relatif lebih baik pada lingkungan sub-optimal dibandingkan dengan tanaman lain (Prihandana dan Hendroko, 2007). Ubi kayu mempunyai prospek yang cukup luas untuk dikembangkan sebagai substitusi beras dan diolah menjadi makanan bergengsi. Pengembangan ubi kayu melalui kegiatan agroindustri cukup baik karena ketersediaan bahan baku melimpah. Melalui program pengembangan industri pangan perlu memanfaatkan bahan baku dalam negeri dan menghasilkan produk-produk yang memiliki nilai tambah tinggi terutama produk siap saji, praktis dan memperhatikan masalah mutu (Lukmito, 1997). Agroindustri merupakan salah satu sub sistem agribisnis yang memiliki posisi strategis dalam paradigma baru karena memiliki beberapa peran penting untuk meningkatkan distribusi pendapatan dan peningkatan pertumbuhan. Untuk menuju pada agroindustri berkelanjutan maka sektor pertanian harus diperkuat karena semua produk agroindustri bersumber dari bahan baku yang disediakan di sektor pertanian (Mckeller dan Smardon, 2012).

Agroindustri sebagai industri yang menggunakan bahan baku pertanian atau proses pengolahan hasil pertanian (Austin, 1992; Hsu, 1997). Proses ini dapat meningkatkan pertumbuhan sektor pertanian melalui peningkatan permintaan produk-produk pertanian. Rustiadi et al. (2009) menyatakan bahwa dengan langkah yang tepat untuk menyeimbangkan pembangunan antara sektor pertanian dan industri maka akan menghasilkan hubungan saling menguntungkan. Sektor industri mampu menampung surplus produksi pertanian sehingga meningkatkan pendapatan sektor pertanian. Demikian juga bila terjadi surplus tenaga kerja di sektor pertanian maka ditampung di sektor industri dan tetap menjaga tingkat pendapatan yang tinggi di sektor pertanian.

Produksi ubi kayu di Kabupaten Maluku Tenggara tahun 2014 sebesar 9.865 ton pada luasan areal 836 ha dengan luas panen 799 ha dan tingkat produktivitas 12,35 ton/ha. Jenis ubi kayu yang dikembangkan adalah jenis ubi kayu berwarna daun keunguan dan disinyalir mengandung syanida sehingga tidak dapat dikonsumsi langsung. Oleh masyarakat setempat ubi kayu tersebut diolah menjadi produk setengah jadi dan diberi nama lokal setempat yaitu "enbal". Enbal memiliki beberapa kelebihan antara lain: 1) sangat mudah untuk perolehan hasil; 2) dapat dikonsumsi oleh semua orang setelah diolah; 3) memiliki daya simpan lama; 4) dapat diolah menjadi aneka makanan siap saji (menu makan malam, makan siang, menu sarapan pagi, dan menu selingan/snack/cemilan); 5) warna hasil olahan putih bersih tanpa pengawet; 6) cocok dijadikan sebagai rasi (beras singkong). Pengembangan ubi kayu menjadi panganan enbal sampai saat sangat baik. Pengrajin selalu mengutamakan proses produksi sehingga kontinutas usaha relatif lancar.
Namun dari sisi efisiensi usaha, apakah usaha agroindustri enbal efisien atau tidak diperlukan sebuah analisis lanjutan. Hal ini penting karena berkaitan dengan penggunaan faktor-faktor produksi yang efisien untuk meningkatkan produksi optimal.

Pengukuran efisiensi relatif agroindustri pangan lokal enbal menggunakan data envelopment analysis. Kirkley et al. (2003) menyatakan bahwa DEA merupakan metode non parametrik atau teknik linear programming untuk menentukan solusi optimal dengan serangkaian kendala. DEA bertujuan untuk mengukur keragaan relatif (relative performance) dari unit analisis pada kondisi keberadaan one input dan multi output, multi input dan one output serta multiple input dan multi output (Dyson et al., 1990 dalam Fauzi dan Anna, 2005). Kumbhaker dan Lovell (2000), mengatakan bahwa efisiensi teknis merupakan salah satu dari komponen efisiensi ekonomi secara keseluruhan. Tetapi, dalam rangka mencapai efisiensi ekonominya suatu perusahaan harus efisien secara teknis. Konsep pengukuran efisiensi dapat dilihat dari sisi input (input-oriented) maupun sisi output (output-oriented). Dalam penelitian ini fokus pengukuran efisiensi bertumpu pada sisi input (inputoriented). Tujuan penelitian adalah menganalisis efisiensi relatif agroindustri enbal.

\section{METODE PENELITIAN}

Penelitian dilakukan pada agroindustri pangan lokal enbal di Desa Debut dan Ngilngof Kabupaten Maluku Tenggara. Penelitian berlangsung pada bulan Mei-Agustus 2015. Sampel penelitian adalah pengrajin agroindustri enbal berjumlah 32 responden yang diklasifikasi menurut jenis produk olahan. Instrumen penelitian yang digunakan adalah kuesioner yang dipakai sebagai panduan untuk wawancara.

\section{Kerangka Analisis}

Analisis efisiensi relatif menggunakan model Data Envelopment Analysis (DEA) yaitu analisis orientasi input (Zhu, 2002). DEA bertujuan untuk mengukur keragaan relatif (relative performance) dari unit analisis pada kondisi keberadaan multi input dan multi output (Dyson et al., 1990 dalam Fauzi dan Anna, 2005). Setiap unit dalam sampel dianggap memiliki tingkat efisiensi yang tidak negatif dengan nilai berkisar antara nol sampai dengan satu. Apabila bernilai satu, maka efisiensinya sempurna. Kemudian unit-unit yang memiliki nilai satu ini digunakan dalam membuat envelope untuk efficiency frontier. Unit-unit lain yang tidak berada pada envelope merupakan unit yang tidak efisien (Hadad et al., 2003).

Data dasar yang digunakan adalah tingkat efisiensi setiap pengrajin sebagai DMU (Decision Making Unit) yang dianalisis yaitu variabel output dan variabel input. DEA mengukur efisiensi dari DMU melalui perbandingan dengan best practice dalam sampel yang diperbandingkan efisiensinya. DEA menunjukkan perhitungan subjektif dari efisiensi operasional pada unit homogen yang dibandingkan satu dengan yang lainnya, 
melalui sejumlah unit sampel yang akan membentuk kurva kinerja frontier yang menjadi batasan bagi semua observasi. Konsekuensinya, DMU yang terletak pada kurva tersebut adalah efisien dalam mendistribusikan input dan memproduksi outputnya, sedangkan DMU yang tidak berada pada kurva dianggap tidak efisien (Al-Delaimi dan Al-Ani, 2006). Pengukuran efisiensi pada dasarnya merupakan rasio antara multi output dan multi input, atau:

Efisiensi = Multi Output / Multi Input

Pengukuran efisiensi untuk multiple input dan output dengan menggunakan pengukuran efisiensi relatif yang diboboti sebagai berikut:

$$
\begin{gathered}
\text { Ef isiensi } D M U=\frac{\sum_{k=1}^{P} w_{k} Y_{k j}}{\sum_{i=1}^{m} v_{i} x_{i j}} \\
=\frac{w_{1} y_{1 j}+w_{2} y_{2 j}+\cdots+w_{k} y_{k j}}{v_{1} x_{1 j}+v_{2} x_{2 j}+\cdots+v_{i} x_{i j}}
\end{gathered}
$$

Keterangan: $\mathrm{w}_{1}=$ Pembobotan untuk output $i ; \mathrm{y}_{1 \mathrm{j}}=$ Jumlah output 1 dari unit $j ; \mathrm{v}_{1}=$ Pembobotan untuk input $1 ; \mathrm{x}_{1 j}=$ Jumlah input 1 ke unit $j ; \mathrm{m}=$ Input-input yang berbeda; $\mathrm{p}=$ Output-output yang berbeda.

DEA diperoleh jika model ditransformasikan ke dalam program linear dengan bobot dari input dan output DMU sebagai variabel keputusan sedangkan nilai (score) efisiensi merupakan fungsi tujuan. Model CCR (Charnes, et al., 1978) dengan input oriented menggunakan asumsi CRS diformulasikan sebagai berikut:

$T E=\operatorname{Min} \theta$

Subject to : $\theta u_{j m} \leq \sum_{j=1}^{J} Z_{j} u_{j m}, m=1,2, \ldots M$

$\sum_{j=1}^{J} Z_{j} x_{j n} \leq x_{j n}, n=1,2, \ldots N$

$$
Z_{j} \geq 0, j=1,2, \ldots J
$$

Model DEA yang memberikan variabel return terskala disebut model BCC (Banker, Charnes dan Cooper) (1984). Model BCC dengan input oriented menggunakan asumsi VRS diformulasikan sebagai berikut:

$T E=\min \theta$

subject to $\sum_{j=1}^{n} \lambda_{j} y_{r j} \geq y_{r}, r=1,2, \ldots, s$

$\theta x_{i}-\sum_{j=1}^{n} \lambda_{j} x_{r j} \geq 0, i=1,2, \ldots, m$

$\sum_{j=1}^{n} \lambda_{j}=1 ; \lambda_{j} \geq 0, j=1,2, \ldots, n$

TE adalah efisiensi teknis untuk DMU ke-j; $\theta$ adalah nilai pengukuran untuk setiap pengamatan $(\leq 1)$; ujm/yrj adalah output ke-j; $x j n / x r j$ adalah input ke-n yang digunakan; $z j / \lambda j$ adalah intensitas penggunaan variabel. Efisiensi teknis menunjukan kemampuan perusahaan untuk mencapai output semaksimal mungkin dari sejumlah input. Sedangkan efisiensi alokatif menunjukan kemampuan perusahaan untuk menggunakan input dengan proporsi seoptimal mungkin pada tingkat harga input tertentu. Kedua komponen ini kemudian dikombinasikan untuk menghasilkan ukuran efisiensi total atau efisiensi ekonomi (Abidin dan Endri, 2009).

Nilai-nilai efisiensi BCC diperoleh dengan menjalankan model di atas untuk setiap DMU. Nilai-nilai efisiensi pengukuran kinerja $\mathrm{BCC}$ disebut nilai efisiensi teknis murni (pure technical efficiency), hal ini terkait dengan nilai-nilai yang diperoleh dari model yang memperbolehkan variabel return terskala, sehingga skala yang ada dapat tereliminasi. Secara umum nilai efisiensi CCR untuk tiap DMU tidak akan melebihi nilai efisiensi $\mathrm{BCC}$, yang memang telah jelas secara intuitif karena model BCC menganalisa tiap DMU secara lokal daripada secara global.

Analisis model input oriented dengan asumsi tingkat pengembalian sama (Constant Return to Scale/CRS) dan tingkat pengembalian tidak sama (Variable Return to Scales/VRS), hasilnya adalah pengrajin efisien berarti mampu mengkombinasikan input dan output secara efisien untuk mencapai output yang ditetapkan. Input yang digunakan adalah enam input antara lain bahan baku, bahan penolong, bahan kemasan, bahan bakar, tenaga kerja dan peralatan. Outputnya adalah jumlah produk olahan. Analisis DEA menggunakan program DEAP versi 2.1 (Coelli, 1996).

\section{HASIL DAN PEMBAHASAN}

\section{Karakteristik Responden}

Pengrajin enbal berumur 45-54 tahun $(54,72 \%)$ berada pada usia produktif. Pengrajin berumur $\geq 65$ tahun termasuk usia non produktif, namun aktivitas produksi lancar. Hal ini dikarenakan pengrajin mengandalkan agroindustri sebagai mata pencaharian utama untuk menunjang nafkah rumah tangga. Umur boleh bertambah tetapi semangat berusaha tidak boleh kendor. Tingkat pendidikan pengrajin enbal sebagian besar SD sebesar 52,45 persen. Tingkat pendidikan tidak menjadi masalah bagi pengrajin untuk mengembangkan usahanya. Sekalipun tingkat pendidikan rendah namun keahlian dan keterampilan berusaha semakin meningkat. Hal ini menyebabkan pengrajin selalu menghasilkan produk-produk baru yang bernilai jual tinggi. Jumlah anggota keluarga pengrajin antara 3-5 orang sebagai sumber tenaga kerja dalam keluarga, untuk membantu kelancaran usaha home industry. Di lokasi penelitian terlihat bahwa pengrajin agroindustri enbal adalah pemiliki tunggal usaha dan dibantu pekerja luar keluarga sebanyak 1-2 orang. Pengalaman berusaha 5-10 tahun, relatif cukup lama ditunjang keterampilan dan keahlian berproduksi sehingga mampu berproses untuk mengembangkan usaha.

Pendapatan pengrajin enbal, rata-rata $\leq 1,5$ juta. Jenis produk olahan lebih sedikit dan upaya penjualan masih berlangsung dalam kabupaten. Aktivitas penjualan produk belum maksimal karena belum banyak produk enbal yang dipasarkan diluar daerah. Sumber keterampilan pengrajin enbal dari orang tua secara turun temurun untuk anggota keluarga. Modal pengrajin bersumber dari modal sendiri. Selain itu, pengrajin memperoleh bantuan uang dan peralatan dari instansi terkait. Bantuan biasanya diberikan untuk kelompok usaha. Pengrajin enbal selain bekerja secara individu 
juga tergabung dalam kelompok, sehingga memudahkan perolehan bantuan dan aktivitas kelompok tetap dibina untuk keutuhan dan kesejahteraan bersama. Hal ini sejalan dengan penelitian Mckeller dan Smardon (2012) bahwa masyarakat mempunyai pandangan positif terhadap agroindustri karena sangat memberikan kontribusi terbesar bagi tingkat kesejahteraan.

Akses teknologi pengolahan lebih banyak dari orang tua. Lainnya pengrajin peroleh dari instansi lain melalui kegiatan penyuluhan, pelatihan dan magang. Promosi produk jarang dilakukan karena terbatas biaya promosi. Bantuan instansi lainnya minim dan sama sekali belum dilakukan sehingga produk olahan hanya dinikmati dalam daerah dan belum banyak sampai ke luar daerah.

Jenis produk enbal yang dihasilkan pengrajin Desa Debut dan Ngilngof antara lain enbal lempeng, enbal bunga, enbal kacang, enbal keju coklat, enbal keju, stik enbal/langaar, rasi enbal, enbal bubuhuk, enbal kukis, dan bangket enbal. Presentase responden untuk pengolahan produk enbal disajikan pada Gambar 1 .

Gambar 1 menunjukkan bahwa jenis-jenis produk enbal diproduksi oleh pengrajin karena memiliki nilai jual yang relatif baik. Tiga produk utama yang rutin diproduksi pengrajin yaitu enbal bunga, enbal kadang dan enbal lempeng. Sedangkan jenis lainnya masih terbatas. Hal ini karena keterbatasan peralatan dan keahlian untuk proses pengolahannya. Dalam perkembangannya pengrajin mulai menciptakan produkproduk baru seperti enbal bubuhuk, enbal kukis dan bangket enbal. Namun ketiga produk ini hanya diolah oleh pengrajin di Desa Debut dan belum banyak tersedia di pasaran. Hal ini disebabkan banyak pengrajin belum mengetahui cara pengolahannya, memiliki keterbatasan pengetahuan, keterbatasan keterampilan dan keahlian untuk menghasilkan produk tersebut. Jenis-jenis produk olahan enbal yang diproduksi pengrajin Desa Debut dan Desa Ngilngof ditampilkan pada Gambar 2.

\section{Analisis Efisiensi Relatif Agroindustri Enbal}

Efisiensi produksi bekaitan dengan kemampuan perusahaan untuk memproduksi suatu produk dengan menggunakan input produksi seminim mungkin (Handfield dan Nichols, 1999). Efisiensi produksi mengacu pada tingkat produksi dimana perusahaan tidak bisa lagi memproduksi jumlah barang tambahan tanpa menurunkan atau mengurangi tingkat produksi dari produk lain. Hal ini akan terjadi ketika sebuah perusahaan beroperasi melampaui batas kemungkinan produksinya. Produksi yang efisien dicapai saat sebuah produk bisa diproduksi dengan rata-rata biaya total yang paling rendah. Efisiensi produksi akan mengukur apakah sistem tersebut mampu memproduksi produk sebanyak mungkin tanpa membuang bahan yang tersedia. Karena bahan baku terbatas, maka memproduksi barang seefisien mungkin akan dapat meningkatkan daya produksi.

Hasil analisis DEA terhadap 32 DMU agroindustri enbal dengan asumsi CRS dan VRS menunjukkan bahwa untuk asumsi CRS diperoleh DMU efisien sebanyak 13 DMU (40,63\%) efisien dan 19 DMU $(59,37 \%)$ inefisien. Rata-rata nilai efisiensi dengan asumsi CRS sebesar 0.877. Pada kondisi ini terdapat DMU yang memiliki nilai efisiensi relatif terendah yaitu DMU 14 dengan nilai efisiensi sebesar 0,577. Hasil analisis ditampilkan pada Tabel 1 .

Tabel 1 menunjukkan bahwa DMU agroindustri enbal yang efisien berdasarkan asumsi CRS antara lain: $1,2,6,10,13,17-19,21,24$, dan 27-29. DMU inefisien adalah 3-5, 7-9, 11-12, 14-16, 20, 22-23, 25-26, dan 3032. Sedangkan berdasarkan asumsi VRS terlihat bahwa DMU efisien antara lain: 1-3, 6, 10-11, 13, 17-19, 21, 24, dan 27-29. Sedangkan DMU inefisien antara lain: 4-5, 7$9,12,14-16,20,22-23,25-26$, dan 30-32.

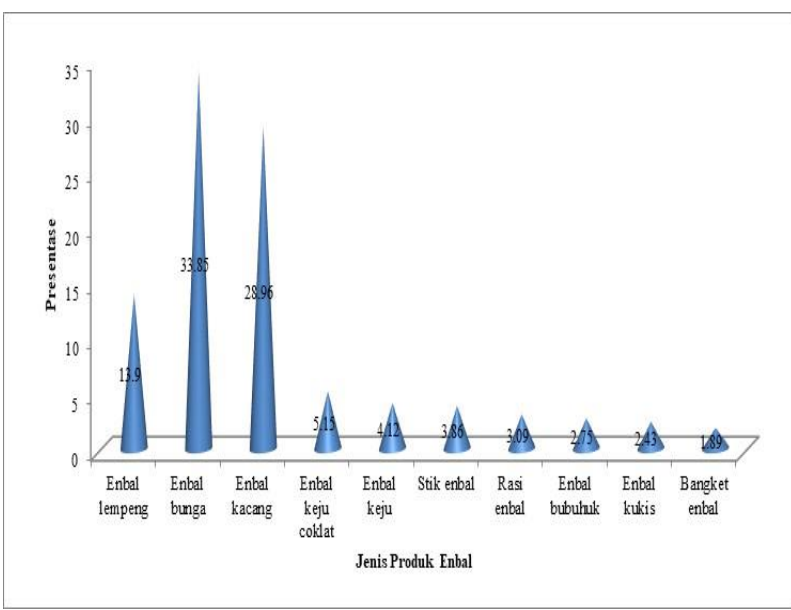

Gambar 1. Presentase responden untuk pengolahan produk enbal
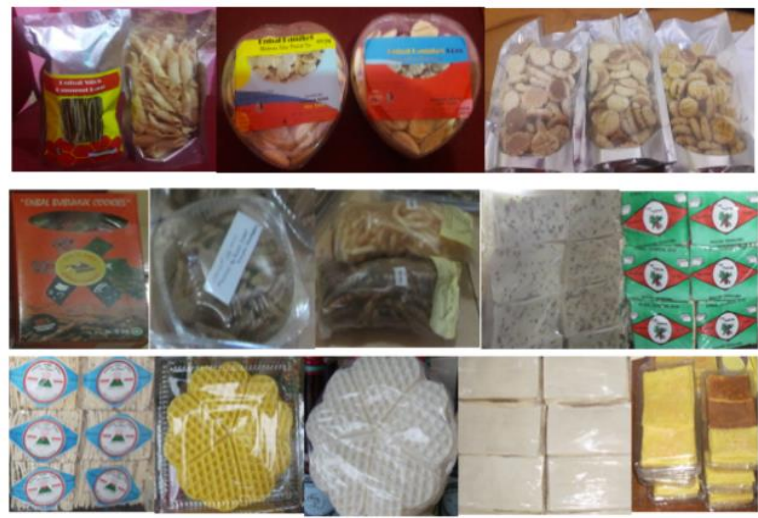

Gambar 2. Jenis produk olahan enbal di Kabupaten Maluku Tenggara

Hasil analisis efisiensi dengan asumsi VRS diperoleh DMU efisien sebanyak 15 DMU $(46,88 \%)$ dan sisanya 17 DMU inefisien $(53,13 \%)$. Rata-rata nilai efisiensi dengan asumsi VRS sebesar 0,949. Sedangkan skala efisiensi sebesar 0,886 . Hasil menunjukkan bahwa DMU inefisien relatif lebih tinggi dibandingkan DMU efisien. Hal ini disebabkan agroindustri belum mengelola sumberdaya secara optimal sehingga nilai efisiensi relatif rendah. Hal ini sejalan dengan hasil penelitian Mardani dan Salarpour (2015) terhadap 23 provinsi penghasil 
kentang bahwa rata-rata tingkat efisiensi teknis tidak 100 persen. Rata nilai efisiensi 0,9 dan skala efisiensi 0,97 . Nilai ini berarti bahwa produsen tidak memanfaatkan input produksi yang lebih efisien. Untuk meningkatkan produksi secara efisien maka harus menurunkan biaya produksi. Produsen harus termotivasi untuk menggunakan teknologi baru untuk meningkatkan produksi dengan meminimalkan penggunaan input produksi. Tingkat efisiensi teknis berdasarkan asumsi CRS, VRS dan skala efisiensi (Gambar 3).

Gambar 3 menunjukkan hasil analisis dengan menggunakan dua asumsi CRS dan VRS, terlihat bahwa untuk asumsi VRS jumlah DMU efisien lebih banyak dibandingkan CRS. Hasil analisis DEA dengan asumsi VRS menunjukkan RTS setiap DMU, berada pada posisi increasing return to scale (IRS), decreasing return to scale (DRS) dan constant return to scale (CRS). Nilai RTS setiap DMU pada posisi economies of scale sebanyak 19 DMU $(59,38 \%)$. Hasil tersebut mengandung makna bahwa saat ini DMU agroindustri enbal dapat mengoptimalkan input yang digunakan secara baik untuk meningkatkan efisiensi.
Gambar 4 menunjukkan bahwa pengoperasian agroindustri enbal dalam jangka pendek cukup baik, meskipun sedikit terjadi kelebihan kapasitas dalam penggunaan input produksi. DMU agroindustri enbal yang berada pada posisi constant return to scale sebanyak 13 DMU atau 40,63\% menunjukkan bahwa pengrajin agroindustri enbal telah menggunakan input produksi secara efisien karena kenaikan produksi sebanding dengan penggunaan input atau penggunaan input lebih proporsional. DMU agroindustri enbal yang berada pada posisi decreasing return to scale sebanyak 5 DMU atau $15,63 \%$ menunjukkan bahwa penggunaan input produksi belum tepat sehingga akan menurunkan output dan terjadi peningkatan biaya produksi. Sedangkan DMU yang berada pada posisi increasing return to scale sebanyak 14 DMU atau $43,75 \%$ menunjukkan bahwa pengrajin menggunakan input produksi tertentu akan menghasilkan DMU efisien, namun kelebihan input dapat menurunkan output sehingga pengrajin harus memperhatikan penggunaan input produksi untuk menghasilkan efisiensi usaha.

Tabel 1. Hasil analisis efisiensi relatif dan skala efisiensi agroindustri enbal

\begin{tabular}{|c|c|c|c|c|}
\hline No & CRS Efisiensi & VRS Efisiensi & Skala Efisiensi & Kriteria \\
\hline 1 & 1,000 & 1,000 & 1,000 & - \\
\hline 2 & 1,000 & 1,000 & 1,000 & - \\
\hline 3 & 0,991 & 1,000 & 0,991 & IRS \\
\hline 4 & 0,733 & 0,979 & 0,749 & DRS \\
\hline 5 & 0,946 & 0,959 & 0,987 & IRS \\
\hline 6 & 1,000 & 1,000 & 1,000 & - \\
\hline 7 & 0,932 & 0,954 & 0,932 & IRS \\
\hline 8 & 0,738 & 0,897 & 0,738 & IRS \\
\hline 9 & 0,750 & 0,879 & 0,750 & IRS \\
\hline 10 & 1,000 & 1,000 & 1,000 & - \\
\hline 11 & 0,778 & 1,000 & 0,778 & IRS \\
\hline 12 & 0,823 & 0,895 & 0,823 & IRS \\
\hline 13 & 1,000 & 1,000 & 1,000 & - \\
\hline 14 & 0,577 & 0,853 & 0,676 & DRS \\
\hline 15 & 0,865 & 0,972 & 0,865 & IRS \\
\hline 16 & 0,950 & 0,875 & 0,950 & IRS \\
\hline 17 & 1,000 & 1,000 & 1,000 & - \\
\hline 18 & 1,000 & 1,000 & 1,000 & - \\
\hline 19 & 1,000 & 1,000 & 1,000 & - \\
\hline 20 & 0,712 & 0,869 & 0,712 & IRS \\
\hline 21 & 1,000 & 1,000 & 1,000 & - \\
\hline 22 & 0,657 & 0,987 & 0,657 & IRS \\
\hline 23 & 0,924 & 0,943 & 0,980 & IRS \\
\hline 24 & 1,000 & 1,000 & 1,000 & - \\
\hline 25 & 0,699 & 0,857 & 0,699 & DRS \\
\hline 26 & 0,692 & 0,886 & 0,782 & DRS \\
\hline 27 & 1,000 & 1,000 & 1,000 & - \\
\hline 28 & 1,000 & 1,000 & 1,000 & - \\
\hline 29 & 1,000 & 1,000 & 1,000 & - \\
\hline 30 & 0,774 & 0,935 & 0,774 & IRS \\
\hline 31 & 0,581 & 0,758 & 0,581 & DRS \\
\hline 32 & 0,941 & 0,874 & 0,941 & IRS \\
\hline Mean & 0,877 & 0,949 & 0,886 & \\
\hline
\end{tabular}

Sumber: Data Primer Olah, 2015 (Hasil Analisis Program DEAP Versi 2.1) 
Perhitungan efisiensi relatif masing-masing DMU menggunakan asumsi CRS dan VRS diperoleh peer dan peers weights untuk dijadikan referensi atau rujukan bagi DMU inefisien. Hasil analisis firm peers dan firm peer weights untuk setiap DMU agroindustri enbal ditampilkan pada Tabel 2 .

Tabel 2 menunjukkan DMU 5 sebagai DMU inefisien dengan score 0,946 . Pola referensinya adalah 19 (0,36), $17(0,32), 13(0,23), 10(0,05)$ dan $24(0,04)$. Untuk menargetkan output DMU 3, maka nilai referensi masing-masing DMU dijumlahkan yaitu DMU 19 ditambah DMU 17 ditambah DMU 13 ditambah DMU 10 ditambah DMU 24. Hal yang sama berlaku untuk DMU lainnya pada agroindustri enbal.

Hasil analisis menunjukkan bahwa DMU 19 digunakan 8 kali sebagai referensi oleh DMU inefisien. Ini karena DMU 19 menghasilkan enam produk secara bersama-sama dan menggunakan input produksi secara proporsional. Sedangkan DMU inefisien karena hampir sebagian besar belum mendiversifikasikan produknya secara baik. Terdapat produk yang belum banyak diolah pengrajin seperti enbal keju coklat, stik enbal/langaar, rasi enbal, enbal kukis, dan bangket enbal, karena mahalnya bahan penolong, keterbatasan peralatan dan mesin pengolahan, dan pengrajin belum memahami teknologi pengolahannya.

DMU efisien perlu mempertahankan aktivitas produksi dengan penggunaan input yang proporsional dan meningkatkan kinerja usaha agroindustrinya. Hal ini sejalan dengan penelitian Timisela, dkk (2017) yakni terciptanya agroindustri yang efisien dalam penggunaan input produksi akan menghasilkan output yang proporsional. DMU inefisien berarti penggunaan input belum proporsional dan tidak sebanding dengan output yang dihasilkan. Sehingga perlu melakukan perubahan dalam penggunaan input dan tingkat output yang dihasilkan lebih proporsional. Hal ini sejalan dengan penelitian Purwanto et al. (2014) bawah DMU yang tidak efisien dapat merujuk pada DMU efisien untuk meminimalkan penggunaan input dan memaksimalkan output yang diperoleh untuk meningkatkan efisiensi usaha secara keseluruhan.

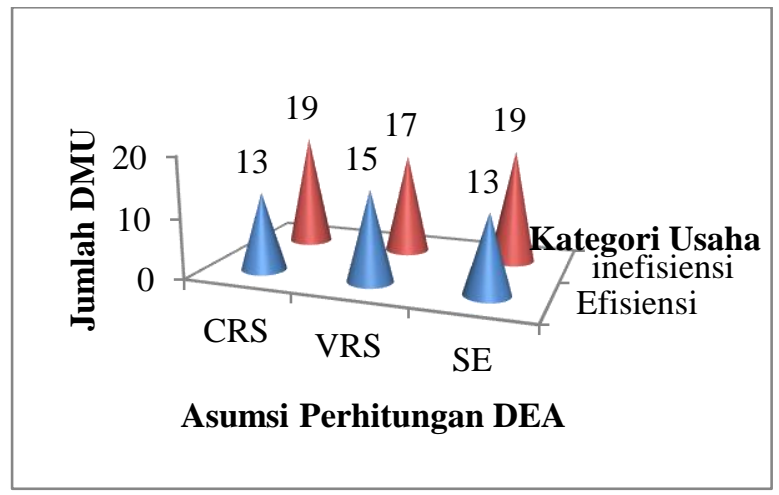

Gambar 3. Kategori efisiensi usaha agroindustri enbal

Peningkatan kreatifitas pengrajin untuk menghasilkan produk berkualitas, rasanya enak, bentuknya menarik, kemasan menarik, aman untuk dikonsumsi, kualitas proses produksi dan lainnya sangat diperlukan sehingga semangat kerja akan semakin bertambah ketika melihat adanya perubahan ke arah yang lebih baik. Perlu adanya peningkatan pengetahuan, teknologi dan keterampilan berusaha, terbuka terhadap informasi-informasi baru seputar pangan lokal dan prospek pengembangannya, perlu memodifikasi produk yang lebih beranekaragam, mencari peluang pasar yang lebih baik, bersinegis dengan pelaku-pelaku bisnis lainnya sehingga terbuka peluang untuk pengembangan usaha.

Agroindustri didasarkan pada pengolahan produk lokal dan proses pengolahan tidak selalu bergantung pada teknologi canggih. Hal ini membuat akses ke peralatan dan bahan baku mudah (Mckeller dan Smardon, 2012). Namun untuk akses ke pasar relatif sulit karena kebanyakan produk agroindustri belum banyak beredar di pasar karena banyak aspek yang harus diperbaiki seperti jaminan kualitas dan kapasitas pengolahan. Hal ini didukung oleh penelitian Oyewole dan Phillip (2006) yang mengusulkan bahwa untuk mengatasi tantangan seperti jaminan kualitas, meningkatkan produksi dan kapasitas pengolahan, dan mengatasi keterbatasan pasar, petani perlu mengatur dan memiliki akses ke pelatihan jaminan kualitas dan pemasaran.

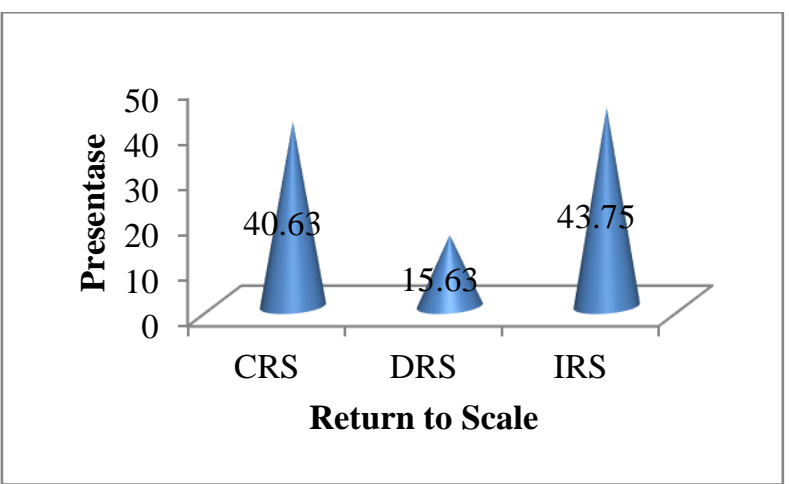

Gambar 4. Kategori return to scale (RTS) agroindustri enbal

\section{KESIMPULAN}

Pengoperasian agroindustri enbal dalam jangka pendek cukup baik, meskipun sedikit terjadi kelebihan kapasitas dalam penggunaan input produksi. DMU agroindustri enbal yang berada pada posisi constant return to scale sebanyak 40,63\% menunjukkan bahwa pengrajin agroindustri enbal telah menggunakan input produksi secara efisien karena kenaikan produksi sebanding dengan penggunaan input atau penggunaan input lebih proporsional. DMU agroindustri enbal yang berada pada posisi decreasing return to scale sebanyak $15,63 \%$ menunjukkan bahwa penggunaan input produksi belum tepat sehingga akan menurunkan output dan terjadi peningkatan biaya produksi. 
Tabel 2. Firm peers dan firm peer weights untuk DMU agroindustri enbal

\begin{tabular}{|c|c|c|c|c|c|c|c|c|c|c|c|}
\hline No. & \multicolumn{5}{|c|}{ Firm Peers } & No. & \multicolumn{5}{|c|}{ Firm Peer Weights } \\
\hline 1 & 1 & & & & & 1 & 1,000 & & & & \\
\hline 2 & 2 & & & & & 2 & 1,000 & & & & \\
\hline 3 & 3 & & & & & 3 & 1,000 & & & & \\
\hline 4 & 20 & 10 & 17 & 7 & 2 & 4 & 0,041 & 0,385 & 0,043 & 0,206 & 0,326 \\
\hline 5 & 19 & 10 & 24 & 13 & 17 & 5 & 0,360 & 0,047 & 0,044 & 0,233 & 0,316 \\
\hline 6 & 6 & & & & & 6 & 1,000 & & & & \\
\hline 7 & 7 & & & & & 7 & 1,000 & & & & \\
\hline 8 & 8 & & & & & 8 & 1,000 & & & & \\
\hline 9 & 24 & 20 & 19 & & & 9 & 0,331 & 0,567 & 0,101 & & \\
\hline 10 & 10 & & & & & 10 & 1,000 & & & & \\
\hline 11 & 20 & 10 & & & & 11 & 0,250 & 0,750 & & & \\
\hline 12 & 12 & & & & & 12 & 1,000 & & & & \\
\hline 13 & 13 & & & & & 13 & 1,000 & & & & \\
\hline 14 & 20 & 8 & 19 & 17 & & 14 & 0,412 & 0,088 & 0,029 & 0,471 & \\
\hline 15 & 15 & & & & & 15 & 1,000 & & & & \\
\hline 16 & 16 & & & & & 16 & 1,000 & & & & \\
\hline 17 & 17 & & & & & 17 & 1,000 & & & & \\
\hline 18 & 18 & & & & & 18 & 1,000 & & & & \\
\hline 19 & 19 & & & & & 19 & 1,000 & & & & \\
\hline 20 & 20 & & & & & 20 & 1,000 & & & & \\
\hline 21 & 21 & & & & & 21 & 1,000 & & & & \\
\hline 22 & 24 & 19 & & & & 22 & 0,750 & 0,250 & & & \\
\hline 23 & 19 & 24 & 17 & 13 & 6 & 23 & 0,442 & 0,136 & 0,015 & 0,164 & 0,243 \\
\hline 24 & 24 & & & & & 24 & 1,000 & & & & \\
\hline 25 & 19 & 17 & 7 & 8 & & 25 & 0,374 & 0,276 & 0,252 & 0,098 & \\
\hline 26 & 19 & 17 & 7 & 8 & & 26 & 0,374 & 0,276 & 0,252 & 0,098 & \\
\hline 27 & 27 & & & & & 27 & 1,000 & & & & \\
\hline 28 & 28 & & & & & 28 & 1,000 & & & & \\
\hline 29 & 29 & & & & & 29 & 1,000 & & & & \\
\hline 30 & 30 & & & & & 30 & 1,000 & & & & \\
\hline 31 & 19 & 24 & 20 & & & 31 & 0,443 & 0,057 & 0,500 & & \\
\hline 32 & 32 & & & & & 32 & 1,000 & & & & \\
\hline
\end{tabular}

Sumber: Data Primer Olah, 2015 (Hasil Analisis Program DEAP Versi 2.1)

Sedangkan DMU yang berada pada posisi increasing return to scale sebanyak $43,75 \%$ menunjukkan bahwa pengrajin menggunakan input produksi tertentu akan menghasilkan DMU efisien, namun kelebihan input dapat menurunkan output sehingga pengrajin harus memperhatikan penggunaan input produksi untuk menghasilkan efisiensi usaha.

\section{UCAPAN TERIMA KASIH}

Terimakasih kepada DP2M Kementerian Riset, Teknologi dan Pendidikan Tinggi yang telah memberikan dana penelitian MP3EI tahun 2015.

\section{DAFTAR PUSTAKA}

Abidin, Z. dan Endri. 2009. Kinerja efisiensi teknis Bank Pembangunan Daerah: Pendekatan data envelopment analysis (DEA). Jurnal Akuntansi dan Keuangan 11: 21-29.

Al-Delaimi, K.S.K. and A.H.B. Al-Ani. 2006. Using data envelopment analysis to measure cost efficiency with an application on Islamic Banks. Scientific Journal of Administrative Development 4: 134156.

Augustyn, G.H., F.J. Polnaya, dan A. Parinusa. 2007. Karakterisasi beberapa sifat pati ubi kayu (Manihot esculenta, Crantz). Buletin Penelitian BIAM 3: 35-39.

Austin, J.E. 1992. Agroindustrial Project Analysis. Critical Design Factors. EDI Series in Economic Development. 2nd edition. The Johns Hopkins University Press. USA.

Charnes, A., W.W. Cooper, and E. Rhodes. 1978. Measuring the efficiency of decision making units. European Journal of Operational Research 2: 429-444.

Coelli, T. 1996. A guide to DEAP Version 2.1: A Data Envelopment Analysis (Computer) Program, CEPA Working Paper 96/08, University of New England, Australia.

Fauzi, A. dan S. Anna. 2005. Pemodelan Sumber Daya Perikanan dan Kelautan untuk Analisis 
Kebijakan. Jakarta: PT Gramedia Pustaka Utama. $343 \mathrm{hlm}$.

Hadad, M.D., W. Santoso, E. Mardanugrah, and D. Ilyas. 2003. Analisis Efisiensi Industri Perbankan Indonesia: Penggunaan Metode Non Parametrik Data Envelopment Analysis (DEA). Research Paper No. 7, Bank Indonesia.

Handfield, R.B. and E.L. Nichols. 1999. Introduction to Supply Chain Management. Prentice Hall Inc.

Hsu, S. 1997. The Agroindustry: A neglected aspect of the location theory of manufacturing. Journal of Regional Science 37: 259-274.

Kirkley, J.E., D. Squires, F.A. Mohammad, and H.O. Ishak. 2003. Capacity and offshore fisheries development: The Malaysian purse seine fishery. In: Pascoe, S and D. Greboval (Eds.). Measuring capacity in fisheries. FAO Fisherier Technical Paper 445: 193-208.

Kumbhaker, S.C. and C.A.K. Lovell. 2000. Stochastic Frontier Analysis. Cambridge, UK: Cambridge University Press.

Lukmito, H. 1997. Strategi Industri Pangan Menghadapi Pasar Global. Majalah Pangan No. 33, Vol. IX. Jakarta.

Mckeller, M.M.M. and R.C. Smardon. 2012. The potential of small-scale agro-industry as a sustainable livelihood strategy in a Caribbean Archipelago Province of Colombia. Journal of Sustainable Development 5: 16-33.

Mardani, M. and M. Salarpour. 2015. Measuring technical efficiency of potato production in Iran using robust data envelopment analysis. Information Processing in Agriculture 2: 6-14.

Oyewole, O.B. and B. Philip. 2006. Agro-food chain and sustainable livelihood: a case study of cassava marketing in Nigeria. Agro-food Chains and Networks for development. Reuben B. and Slingerland (Eds). Springer, Netherlands 14: 107115.

Polnaya, F.J., R. Breemer, G.H. Augustyn, dan H.C.D. Tuhumury. 2015. Karakteristik sifat-sifat fisikokimia pati ubi jalar, ubi kayu, keladi dan sagu. Agrinimal 5: 37-42.

Prihandana, R. dan R. Hendroko. 2007. Energi Hijau. Jakarta: Penebar Swadaya.

Purwanto, D. Manongga, and M.A.I. Pakereng. 2014. Efficiency of small and medium-sized Tofu Enterprises (SME) in Salatiga using Data Envelopment Analysis (DEA). International Journal of Computer Applications 91: 44-50.

Rustiadi, E., S. Saefulhakim, dan D.R. Panuju. 2009. Perencanaan dan Pengembangan Wilayah. Jakarta: Yayasan Obor Indonesia.

Timisela, N.R., E.D. Leatemia, F.J. Polnaya, dan R. Breemer. 2017. Supply chain management of agro industry of cassava. Journal of Applied Management 15: 135-145.

Zhu, J. 2002. Quantitative Models for Performance Evaluation and Benchmarking Data Envelopment Analysis with Spreadsheets and DEA Excel Solver. Massachusetts: Kluwer Academic Publisher. 